\title{
Raloxifene- and estradiol-mediated effects on uterus, bone and B lymphocytes in mice
}

\author{
M C Erlandsson, C A Jonsson, M K Lindberg ${ }^{1}$, C Ohlsson ${ }^{1}$ and \\ H Carlsten \\ Department of Rheumatology and Inflammation Research, University of Göteborg, Guldhedsgatan 10A, S-413 46 Göteborg, Sweden \\ ${ }^{1}$ Research Center for Endocrinology and Metabolism, Department of Internal Medicine, University of Göteborg, Göteborg, Sweden \\ (Requests for offprints should be addressed to M C Erlandsson; Email: malin.erlandsson@rheuma.gu.se)
}

\begin{abstract}
Raloxifene is a selective estrogen receptor modulator approved for the prevention of osteoporosis in postmenopausal women. It is selective by having estrogen-agonistic effects on bone, vessels and blood lipids while it is antagonistic on mammary and uterine tissue. Our aim was to study the agonistic and antagonistic properties of the raloxifene analogue LY117018 (LY) on uterus, bone, B lymphopoiesis and B cell function.

Oophorectomized and sham-operated animals were treated with s.c. injections of equipotent anti-osteoporotic doses of $17 \beta$-estradiol (E2) $(0.1 \mathrm{mg} / \mathrm{kg})$ or LY $(3 \mathrm{mg} / \mathrm{kg})$ or vehicle as controls. Effects on bone mineral density (BMD) were studied using peripheral quantitative computed tomography, uterine weight was examined,
\end{abstract}

B lymphopoiesis was examined using flow cytometry and $\mathrm{B}$ cell function in bone marrow and spleen was studied by the use of an ELISPOT assay.

E2 and LY had similar effects on BMD and bone marrow B lymphopoiesis, while LY had a clear antagonistic effect on endogenous estrogen in uterine tissue and no stimulating effect on the frequency of Ig-producing B cells in sham-operated animals. Our results are discussed in the context of estrogen receptor biology, relations between the immune system and bone metabolism and also with respect to the estrogen-mediated effects on rheumatic diseases.

Journal of Endocrinology (2002) 175, 319-327

\section{Introduction}

Raloxifene is a selective estrogen receptor modulator (SERM) approved to prevent and treat osteoporosis in postmenopausal women (Delmas et al. 1997). It is selective by having estrogenic effects on blood lipids and bone formation (Delmas et al. 1997), while it is antagonistic on breast tissue (Cummings et al. 1999) and uterus (Black et al. 1994, Sato et al. 1996). Women with an accelerated risk of developing cancer in these tissues can therefore use raloxifene to prevent or treat osteoporosis.

The immune system is influenced by estradiol (E2) in a diverse manner. Removal of estrogen by means of oophorectomy enhances the number of B lymphopoietic cells in bone marrow in mice (Masuzawa et al. 1994) and, if E2 is given back, B lymphopoiesis is down-regulated, now with a shift towards more mature B cells (Medina et al. 2000). The erythroid and myeloid precursors are not altered after estrogen exposure (Medina et al. 1993). The effect of estrogen on B cells is recognized as enhanced Ig production in the rat (Dahlgren \& Hanson 1991) and the mouse (Nilsson \& Carlsten 1994). In addition, E2 induces dramatic thymic atrophy, including a shift towards more mature thymocytes (Rijhsinghani et al. 1996), and inhibits natural killer cell-mediated cytotoxicity (Hanna \& Schneider 1983), and suppresses granulocyte- (Josefsson et al. 1992) and $\mathrm{T}$ cell-mediated (Carlsten et al. 1996) inflammation. The immune-regulating properties of estrogen can influence the outcome of certain autoimmune diseases. Thus, endogenous or added estrogen accelerates the progression of immune complex-mediated murine (Carlsten et al. 1990) and human (Ostensen 1999) systemic lupus erythematosus (SLE) but ameliorates $\mathrm{T}$ cell- and macrophage-mediated experimental (Holmdahl et al. 1989) and human rheumatoid arthritis (RA) (Ostensen 1999).

Bone resorption following estrogen deficiency is primarily caused by increased numbers of bone-resorbing osteoclasts (Pacifici 1996), which formerly were believed to develop exclusively from stem cells of myelopoietic lineage. However, it has recently been shown that osteoclasts can also be formed from early B cells (Manabe et al. 2001, Sato et al. 2001).

The effects of raloxifene on the immune system are as yet poorly investigated. Recently, we demonstrated that oophorectomized mice treated with the raloxifene 
analogue LY117018 (LY) underwent partial thymic atrophy, but failed to shift thymocytes towards more mature $\mathrm{T}$ cells. We also showed that LY lacks the suppressive effects of estrogen on granulocyte- and $\mathrm{T}$ cell-mediated inflammation (Erlandsson et al. 2000). The aim of the present study was to examine how LY affects B lymphopoiesis in the bone marrow and the function of $\mathrm{B}$ cells in bone marrow and spleen. We treated both oophorectomized and sham-operated animals with LY, E2 or vehicle control in order to identify areas where raloxifene acts in an antagonistic and/or an agonistic manner compared with endogenous estrogen.

\section{Materials and Methods}

\section{Mice}

C57BL/6 mice were bought from Bomholtgård Ltd (Ry, Denmark). They were housed five to ten animals in each cage under standard conditions of temperature and light and fed standard laboratory chow ad libitum.

\section{Castration}

All mice were castrated at the age of 5-6 weeks. Ovaries were removed after a flank incision and the incisions were closed with metallic clips. The oophorectomy was carried out under Hypnorm/Dormicum anesthesia. Sham-operation was carried out in a manner similar to oophorectomy, but excluding the removal of the ovaries. Mice were left to rest for 1 week after operation before the start of the experiments. The experiments were approved by the local ethics committee for animal research.

\section{Hormones and treatment}

The hormones used were $17 \beta$-estradiol benzoate (E2; Sigma, St Louis, MO, USA) and the raloxifene analogue LY117018 free base (LY), kindly donated by Eli Lilly Corporation, Indianapolis, IN, USA. Raloxifene is a non-steroid hormone based on benzothiophene. LY differs from raloxifene at only one site in the molecule: instead of a pyrrolidine ring it has a piperidine ring on the basic side chain. The mice were treated, as previously described (Erlandsson et al. 2000), with s.c. injections of $3 \mathrm{mg}$ $\mathrm{LY} / \mathrm{kg}$, or $0.1 \mathrm{mg} \mathrm{E} 2 / \mathrm{kg}$ dissolved in $100 \mu \mathrm{l}$ olive oil (Apoteksbolaget, Göteborg, Sweden) for 5 days/week for 2.5 weeks. Controls were given vehicle $(100 \mu \mathrm{l}$ olive oil/mouse) for 5 days/week. The doses were chosen as equipotent to those for treating osteoporosis (Sato et al. 1995).

\section{Cellular parameters}

Tissue collection and single cell preparation The mice were killed by cervical dislocation. Uteri and spleens were autopsied and weighed. Spleen single cell suspensions were obtained after tissue was mashed and passed through a nylon wool sieve. The cells were centrifuged at $515 \mathrm{~g}$ for $5 \mathrm{~min}$ and pelleted spleen cells were resuspended in Tris-buffered $0.83 \% \mathrm{NH}_{4} \mathrm{Cl}$ solution ( $\left.\mathrm{pH} 7 \cdot 29\right)$ to lyse erythrocytes. Bone marrow cells were harvested from the cavity of the right femur using a syringe with $2 \mathrm{ml}$ phosphate-buffered serum (PBS). Cells were kept in complete Iscove's medium (Invitrogen, Carlsbad, CA, USA)/PBS (50/50) until use. After being washed in PBS, the total number of leukocytes was calculated, using an automated cell counter (Sysmex, Kobe, Japan), the cells were subjected to Fluorescence Activated Cell Sorting (FACS) analysis and an Enzyme Linked ImmunoSPOT (ELISPOT) assay to determine the number of Igproducing cells.

Flow cytometry for analysis of cell phenotypes Isolated splenocytes were stained with fluorescein isothiocyanate (FITC)-labeled antibodies to CD45R/B220 (clone RA3-6B2) (Beckton-Dickinson, Franklin Lakes, NJ, USA) and phycoerythrin (PE)-conjugated antibodies to CD3e (clone 145-2C11) (Beckton-Dickinson). Bone marrow cells were labeled with $\alpha$ CD45R/B220-FITC and PE-conjugated antibodies to the immunoglobin heavy chain $\mu$ (clone 1021-09) (Southern Biotechnology Inc., Birmingham, AL, USA). All cells were analysed in a FACSCalibur (Beckton-Dickinson). Stained cells were expressed as percentage of gated mononuclear cells.

ELISPOT The ELISPOT technique (Czerkinsky et al. 1984) was used for evaluation of IgG-, IgM- and IgAsecreting bone marrow and spleen cells. Briefly, 96-well nitro-cellulose plates (Millipore, Bedford, MA, USA) were coated with $100 \mu \mathrm{l}$ PBS containing $5 \mu \mathrm{g} / \mathrm{ml}$ affinity purified $\mathrm{F}\left(\mathrm{ab}^{\prime}\right)_{2}$ fragments of goat anti-mouse $\operatorname{IgG}, \operatorname{IgM}$ and IgA (Southern Biotechnology Inc.). After overnight incubation at $4{ }^{\circ} \mathrm{C}$ and blocking with $5 \%$ fetal calf serum, $50 \mu \mathrm{l}$ Iscove's culture medium containing $10^{6}$ or $10^{5}$ freshly isolated spleen or bone marrow cells was added to each well. The plates were incubated for $3.5 \mathrm{~h}$ at $37^{\circ} \mathrm{C}$ in $5 \% \mathrm{CO}_{2}$ and $95 \%$ humidity. After being rinsed, each well was incubated stepwise with $100 \mu$ l alkaline phosphataseconjugated goat anti-mouse $\operatorname{IgG}, \operatorname{IgM}$ or IgA diluted in 1:750 PBS and finally with the substrate 5-bromo-4chloro-3-indolyl phosphate (Sigma). After $1 \mathrm{~h}$, the reaction was stopped by washing in tap water and each well was examined for the appearance of dark blue spots. The samples were run in triplicate and the numbers of Igsecreting cells were expressed as the frequency of spotforming cells $(\mathrm{SFC}) / 10^{3} \mathrm{~B} 220^{+}$cells.

\section{Histological parameters}

Peripheral quantitative computed tomography (pQCT) Tomographic measurements were made using the Stratec pQCT XCT Research M specifically modified 
for use on small bone specimens (software version 5.4B; resolution $70 \mu \mathrm{m}$; Norland, Fort Atkinson, WI, USA). Ex vivo metaphyseal $\mathrm{pQCT}$ scans of the distal metaphyseal part of the left femur were used to measure bone mineral density (BMD) as previously described (Vidal et al. 2000).

\section{Serological parameters}

Serum Blood was collected at the termination of the experiments. The sera were individually stored at $-20^{\circ} \mathrm{C}$ until use.

E2 radioimmunoassay (RIA) Serum E2 levels were measured using an E2 RIA (DSL-39100) scaled down 1:4 (Diagnostic Systems Laboratories Inc., Webster, TX, USA). The sensitivity of the assay is less than $1 \mathrm{pg} / \mathrm{ml}$.

Insulin-like growth factor-I (IGF-I) RIA Serum IGF-I levels were measured by double-antibody IGFbinding protein-blocked RIA, according to Blum \& Brier (1994).

\section{Statistical analysis}

Unpaired $t$-test was used for statistical comparisons between means of different treatment groups. Results are presented as means \pm S.E.M. A $P$ value $<0 \cdot 05$ was considered statistically significant.

\section{Results}

\section{Effects on uterus and bone}

Oophorectomized (OVX) and sham-operated mice were treated with $\mathrm{E} 2$ or LY in doses equipotent with those used for the prevention of osteoporosis. In both OVX and sham-operated groups, exposure to E2 resulted in similar and highly elevated uterus weights, whereas OVX control animals displayed low uterus weights with very small inter-individual variations (Table 1). In both OVX and sham-operated groups, treatment with LY induced intermediate uterus weights, again with small inter-individual varations. Thus, exposure to LY reduces uterus weight in sham-operated animals but increases it in OVX animals, clearly demonstrating both antagonistic and agonistic effects of LY in the uterus. Serum levels of E2 were measured after the end of the experiment and the outcome was as expected, low levels in non-treated and LYexposed sham-operated animals, significantly lower in OVX animals and significantly higher in both E2 treatment groups (Table 1).

The distal metaphyseal part of the femur was subjected to $\mathrm{pQCT}$ analysis of BMD. As expected, a significant reduction in BMD was found upon OVX (Table 2). Exposure to both E2 and LY induced a significant increase
Table 1 Uterus weight and serum E2 levels of mice after 2.5 weeks of hormone treatment. Values are means \pm S.E.M.

\begin{tabular}{|c|c|c|c|c|}
\hline & Treatment & $n$ & $\begin{array}{l}\text { Uterus } \\
\text { weight } \\
(\mathrm{mg})\end{array}$ & $\begin{array}{l}\text { Serum E2 } \\
\text { level } \\
(\mathrm{pg} / \mathrm{ml})\end{array}$ \\
\hline \multicolumn{5}{|l|}{ Operation } \\
\hline \multirow[t]{3}{*}{ Sham } & $\begin{array}{c}\text { Controls (C) } \\
\text { C vs E2 }\end{array}$ & 6 & $\begin{array}{l}92 \pm 19 \\
\mathrm{~ns}\end{array}$ & $\begin{array}{l}12 \pm 3 \\
* *\end{array}$ \\
\hline & $\begin{array}{c}0 \cdot 1 \mathrm{mg} \mathrm{E} 2 / \mathrm{kg} \\
\text { E2 vs LY }\end{array}$ & 6 & $\begin{array}{l}164 \pm 28 \\
* *\end{array}$ & $\begin{array}{l}58 \pm 12 \\
* *\end{array}$ \\
\hline & $\begin{array}{c}3 \mathrm{mg} \mathrm{LY} / \mathrm{kg} \\
\mathrm{C} \text { vs LY }\end{array}$ & 6 & $\begin{array}{l}53 \pm 1 \\
\mathrm{~ns}\end{array}$ & $\begin{array}{l}13 \pm 1 \\
\mathrm{~ns}\end{array}$ \\
\hline \multirow[t]{3}{*}{ ovx } & $\begin{array}{l}\text { Controls } \\
\text { C vs E2 }\end{array}$ & 10 & $\operatorname{lit}_{* * *} \pm 1^{\neq \neq \neq}$ & $\underset{* * *}{6 \pm 1^{\ddagger}}$ \\
\hline & $\begin{array}{c}0 \cdot 1 \mathrm{mg} \mathrm{E} 2 / \mathrm{kg} \\
\text { E2 vs LY }\end{array}$ & 10 & $\begin{array}{l}155 \pm 19 \\
* * *\end{array}$ & $\begin{array}{l}62 \pm 13 \\
* * *\end{array}$ \\
\hline & $\begin{array}{c}3 \mathrm{mg} \mathrm{LY} / \mathrm{kg} \\
\text { C vs LY }\end{array}$ & 10 & $\underset{* \star *}{35} \pm 2^{\neq \neq \neq}$ & $\begin{array}{l}8 \pm 2 \\
\mathrm{~ns}\end{array}$ \\
\hline
\end{tabular}

${ }^{* *} P<0 \cdot 01,{ }^{* * *} P<0 \cdot 001$

${ }^{\ddagger} P<0 \cdot 05, \stackrel{\nexists \neq \ddagger}{ } P<0 \cdot 001$ (OVX vs sham). ns, not significant.

in BMD in sham-operated and OVX animals (Table 2 and Fig. 1). The effect of E2 treatment was, however, slightly but significantly larger than the effect of LY treatment in both sham-operated and OVX animals.

\section{Effects on bone marrow B lymphopoiesis}

Bone marrow cells from OVX or sham-operated mice treated for 2.5 weeks with E2 or LY were labeled with monoclonal antibodies to $\mathrm{B} 220^{+}$and the $\operatorname{IgM} \mu$-chain and subjected to FACS analysis. In control mice, OVX resulted in an increased frequency of $\mathrm{B}$ lymphopoietic $\left(\mathrm{B} 220^{+}\right)$cells. In both the OVX and the sham-operated group, treatment with both E2 and LY resulted in decreased frequency of $\mathrm{B} 220^{+}$cells (Fig. 2).

The B220 ${ }^{+}$cells were divided into four groups in order of appearance in the $\mathrm{B}$ cell maturation: $\mathrm{B} 220^{\mathrm{low}_{\mu}} \mu^{-}$(1), $\mathrm{B} 220^{\mathrm{low}} \mu^{+}$(2), B220 $0^{\text {high }} \mu^{+}$(3) and B220 high $\mu^{-}$(4).

Table 2 BMD of the distal metaphyseal part of the femur of mice after 2.5 weeks of hormone treatment. Values are means \pm S.E.M.

\begin{tabular}{|c|c|c|c|c|c|}
\hline & $\begin{array}{l}\text { Sham } \\
\left(\mathrm{mg} / \mathrm{cm}^{3}\right)\end{array}$ & $n$ & $\begin{array}{l}\boldsymbol{P} \\
\text { (sham vs } \\
\text { OVX) }\end{array}$ & $\begin{array}{l}\text { OVX } \\
\left(\mathrm{mg} / \mathrm{cm}^{3}\right)\end{array}$ & $n$ \\
\hline Treatment & & & & & \\
\hline $\begin{array}{c}\text { Controls (C) } \\
\text { C vs E2 }\end{array}$ & $\begin{array}{l}460 \pm 15 \\
* * *\end{array}$ & 6 & $* * *$ & $\begin{array}{l}371 \pm 6 \\
* * *\end{array}$ & 10 \\
\hline $\begin{array}{c}0 \cdot 1 \mathrm{mg} \mathrm{E} 2 / \mathrm{kg} \\
\text { E2 vs LY }\end{array}$ & $\underset{* *}{598} \pm 17$ & 6 & ns & $\begin{array}{l}574 \pm 15 \\
*\end{array}$ & 10 \\
\hline $\begin{array}{c}3 \mathrm{mg} \mathrm{LY} / \mathrm{kg} \\
\mathrm{C} \text { vs LY }\end{array}$ & $\begin{array}{l}511 \pm 16 \\
*\end{array}$ & 6 & * & $\begin{array}{l}523 \pm 10 \\
* * *\end{array}$ & 10 \\
\hline
\end{tabular}

Journal of Endocrinology (2002) 175, 319-327 


\section{Control}

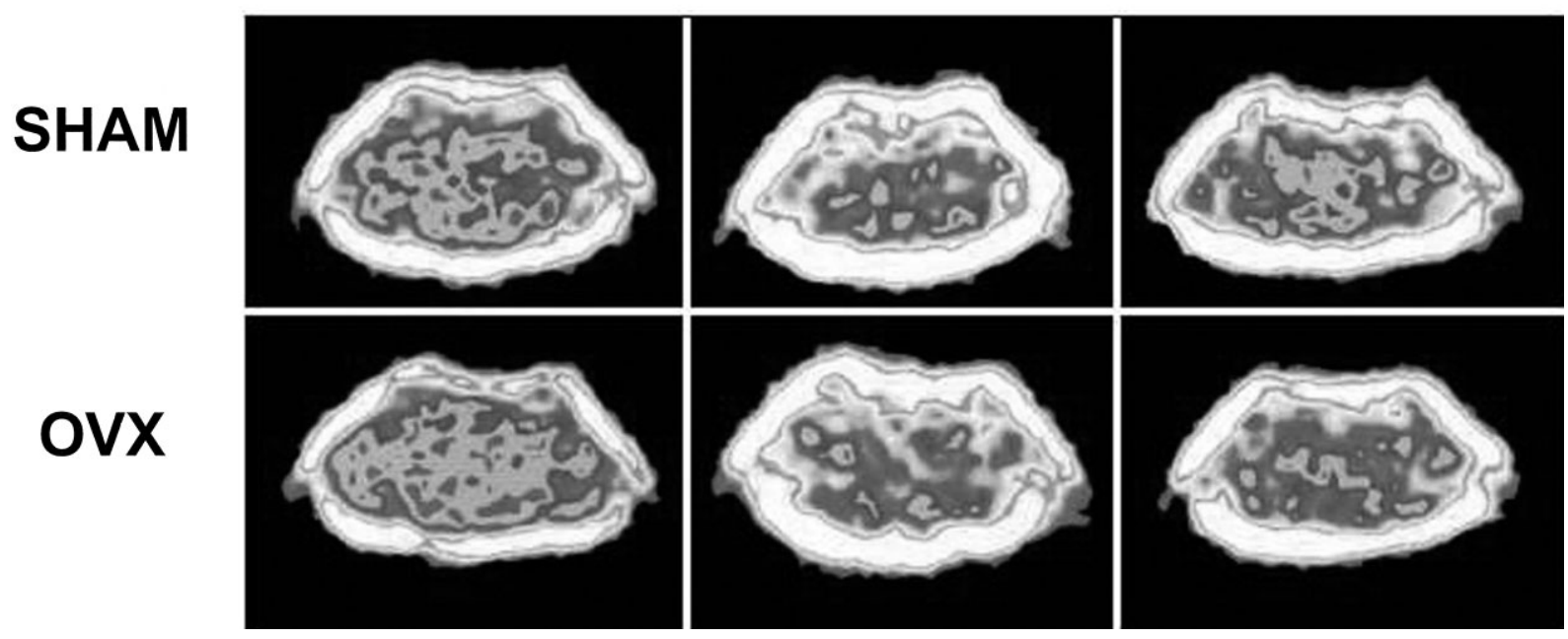

Figure 1 Representative pQCT scans of the distal metaphysis of the femur of OVX or sham-operated mice treated 5 days/week for 2.5 weeks with $0.1 \mathrm{mg} / \mathrm{kg} \mathrm{E2}, 3 \mathrm{mg} / \mathrm{kg}$ LY or olive oil as controls. Pictures are representatives from each group consisting of six to ten mice/group. Means \pm S.E.M. are shown in Table 2.

Table 3 shows that OVX resulted in decreased frequency of mature $\mathrm{B} 220^{\text {high }} \mathrm{B}$ cells whereas the treatment of sham-operated and OVX mice with E2 or LY induced a significant shift of $\mathrm{B}$ lymphopoietic cells from immature $\mathrm{B} 220^{\text {low }}$ cells to more mature $\mathrm{B} 220^{\text {high }}$ cells. Representative FACS plots are shown in Fig. 3.

Bone marrow cells were subjected to an Ig isotypespecific ELISPOT assay for evaluation of Ig-producing cells. Exposure to E2 increased the frequency of Igproducing cells (measured as Ig SFC $/ 10^{3} \mathrm{~B} 220^{+}$cells) in both sham-operated animals and the OVX group (Fig. 4). In contrast, a similar increase in frequency of Ig-producing cells was seen in LY-exposed OVX mice but not in sham-operated animals.

\section{Effects on spleen cells}

Spleen cellularity was significantly lower after E2 or LY treatment in both the OVX and the sham-operated animals (Table 4). Splenocytes from all treatment groups were labeled with monoclonal antibodies to B220 and CD3 and subjected to FACS analysis. After OVX, both hormones induced a lower frequency of $\mathrm{B} 220^{+}$cells in spleen, a phenomenon not seen in sham-operated mice (Table 4). When the number of $\mathrm{B} 220^{+}$spleen cells was calculated, both treatments resulted in a lower number on both backgrounds (sham-operated and OVX) (Table 4). A similar result was found for the number of $\mathrm{CD}^{+}$spleen cells (data not shown).
Spleen cells were subjected to an Ig isotype-specific ELISPOT assay for evaluation of Ig-producing cells. In OVX animals, E2 treatment led to a higher frequency of Ig-producing $\mathrm{B}_{22} 0^{+}$cells, while LY treatment did not alter the frequency. Sham-operated animals had significantly higher frequencies of Ig upon treatment with E2, but not after treatment with LY (Fig. 5).

\section{Effects on serum IGF-I levels}

In OVX mice, treatment with E2 resulted in slightly decreased serum IGF-I levels not seen in LY-exposed mice. In contrast, sham-operated animals treated with LY displayed significantly higher IGF-I levels, whereas exposure to E2 did not alter IGF-I levels, possibly indicating the antagonistic properties of raloxifene (Table 5).

\section{Discussion}

The aim of the present report was to study the agonistic and antagonistic properties of the raloxifene analogue LY117018 to endogenous estrogen in uterus, bone, on $\mathrm{B}$ lymphopoiesis in bone marrow and on B lymphocytes in spleen.

It was previously shown that raloxifene exerts a minor agonistic effect on the uterus in castrated rats (Black et al. 1994). We have now shown not only a weak agonistic 
Table 3 B lymphopoietic phenotypes (\%) in mice treated with E2 or LY for 2.5 weeks. Values are means \pm S.E.M.

\begin{tabular}{|c|c|c|c|c|c|c|}
\hline & Treatment & $n$ & B220 low $\boldsymbol{\mu}^{-(1)}$ & B220 ${ }^{\text {low }} \boldsymbol{\mu}^{+(1)}$ & B220 high $\mu^{+(1)}$ & B220 ${ }^{\text {high }} \boldsymbol{\mu}^{-(1)}$ \\
\hline \multicolumn{7}{|c|}{ Operation } \\
\hline \multirow[t]{3}{*}{ Sham } & $\begin{array}{c}\text { Controls (C) } \\
\text { C vs E2 }\end{array}$ & 6 & $\begin{array}{l}43 \cdot 8 \pm 2 \cdot 8 \\
*\end{array}$ & $\begin{array}{l}36 \cdot 3 \pm 1 \cdot 7 \\
* * *\end{array}$ & ${ }_{* * *}^{16 \cdot 2} \pm 2 \cdot 5$ & $\begin{array}{l}3 \cdot 7 \pm 0 \cdot 9 \\
\text { ns }\end{array}$ \\
\hline & $\begin{array}{c}0 \cdot 1 \mathrm{mg} \mathrm{E} 2 / \mathrm{kg} \\
\text { E2 vs LY }\end{array}$ & 6 & $\begin{array}{l}32 \cdot 6 \pm 2 \cdot 5 \\
\text { ns }\end{array}$ & $\begin{array}{l}19 \cdot 3 \pm 1 \cdot 5 \\
\text { ns }\end{array}$ & $\begin{array}{l}41 \cdot 1 \pm 3 \cdot 9 \\
\mathrm{~ns}\end{array}$ & $\begin{array}{l}7 \cdot 0 \pm 1 \cdot 2 \\
\mathrm{~ns}\end{array}$ \\
\hline & $\begin{array}{c}3 \mathrm{mg} \mathrm{LY} / \mathrm{kg} \\
\mathrm{C} \text { vs LY }\end{array}$ & 6 & $\underset{* * *}{26 \cdot 9} \pm 2 \cdot 2$ & $\begin{array}{l}19 \cdot 2 \pm 1 \cdot 2 \\
* * *\end{array}$ & $\begin{array}{l}47 \cdot 9 \pm 2 \cdot 8 \\
* * *\end{array}$ & $\begin{array}{l}6 \cdot 0 \pm 0 \cdot 2 \\
*\end{array}$ \\
\hline \multirow[t]{3}{*}{ OVX } & $\begin{array}{l}\text { Controls } \\
\text { C vs E2 }\end{array}$ & 10 & $\begin{array}{l}58 \cdot 5 \pm 2 \cdot 0^{\neq \neq *} \\
\neq \neq *\end{array}$ & ${ }_{* * *}^{30 \cdot 2} \pm 0 \cdot 8^{\neq \neq}$ & $\begin{array}{l}10 \cdot 3 \pm 1 \cdot 5^{\ddagger} \\
* * *\end{array}$ & 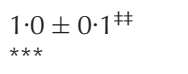 \\
\hline & $\begin{array}{c}0 \cdot 1 \mathrm{mg} \mathrm{E} 2 / \mathrm{kg} \\
\text { E2 vs LY }\end{array}$ & 10 & ${\underset{* *}{*}}^{39 \cdot 0} \pm 2 \cdot 9$ & $\begin{array}{l}14 \cdot 4 \pm 1 \cdot 2^{\ddagger} \\
\text { ns }\end{array}$ & $\begin{array}{l}37 \cdot 0 \pm 3 \cdot 3 \\
* *\end{array}$ & $\begin{array}{l}9 \cdot 6 \pm 1 \cdot 0 \\
n s\end{array}$ \\
\hline & $\begin{array}{c}3 \mathrm{mg} \mathrm{LY} / \mathrm{kg} \\
\mathrm{C} \text { vs LY }\end{array}$ & 10 & $\begin{array}{l}49 \cdot 5 \pm 1 \cdot 8^{\neq \neq \neq} \\
* *\end{array}$ & ${ }_{* * *}^{17 \cdot 6 \pm 1 \cdot 9}$ & $\begin{array}{l}24 \cdot 5 \pm 1 \cdot 7^{\neq \neq \neq} \\
* \star \star\end{array}$ & $\begin{array}{l}8 \cdot 4 \pm 0 \cdot 6^{\neq \neq} \\
* \star *\end{array}$ \\
\hline
\end{tabular}

\footnotetext{
${ }^{(1)} \%$ of $\mathrm{B} 220^{+}$bone marrow cells.

${ }^{*} P<0 \cdot 05,{ }^{* *} P<0 \cdot 01,{ }^{* * *} P<0 \cdot 001$.

${ }^{\ddagger} P<0 \cdot 05,{ }^{\ddagger} P<0 \cdot 01,{ }^{\ddagger} \neq \neq P<0 \cdot 001$ (OVX vs sham).

ns, not significant.
}

effect of LY on OVX mice but also a clear antagonistic effect on sham-operated animals (Table 1). In a recent study, using low doses of E2 and raloxifene in normal mice, the uterus weight was decreased, but not enough to be significant (Onoe et al. 2000). A study on ovulating women revealed only minor antagonistic effects on their endometrial biopsy specimens after raloxifene treatment (Baker et al. 1998). We therefore believe that raloxifene acts as a competing antagonist to endogenous estrogen at the estrogen receptor (ER) level in the uterus. This is supported by studies carried out in vitro where endometrial cancer cells were treated with a combination of E2 and raloxifene (Kleinman et al. 1996).

Castration of both males and females induces osteoporosis. Physiological doses of estrogen restore the BMD whereas osteopetrosis is induced when pharmacologically high doses are given (Samuels et al. 1999). Raloxifene has the same properties of bone formation as estrogen, but requires a dose of about 30-fold (Sato et al. 1995). In the present study, exposure to both E2 and LY induced a significant increase in BMD in sham-operated and OVX animals (Table 2).

Castration of both male and female mice induces an increased number of nucleated cells in bone marrow. The selectively expanding cell population consists of early B lymphopoietic B220 ${ }^{+}$cells (Masuzawa et al. 1994). If estrogen is replaced, the frequency of $\mathrm{B} 220^{+}$cells is reduced in a dose-dependent manner (Onoe et al. 2000) and there is a shift towards higher frequencies of more mature B cells (Medina et al. 2000). We have now shown that exposure to LY induces the same pattern of shift, independent of hormonal background (sham-operated or OVX) (Fig. 3 and Table 3). Recently Onoe et al. (2000) presented a similar shift of $\mathrm{B}$ cell frequencies in OVX animals treated with raloxifene but, in contrast to our work, when treating sham-operated mice they did not find any difference between controls and raloxifene-treated animals, possibly due to lower treatment doses.

The effects of LY treatment shown above are similar to the known E2-induced effects on both bone and B lymphopoiesis. Bone metabolism is a delicate balance

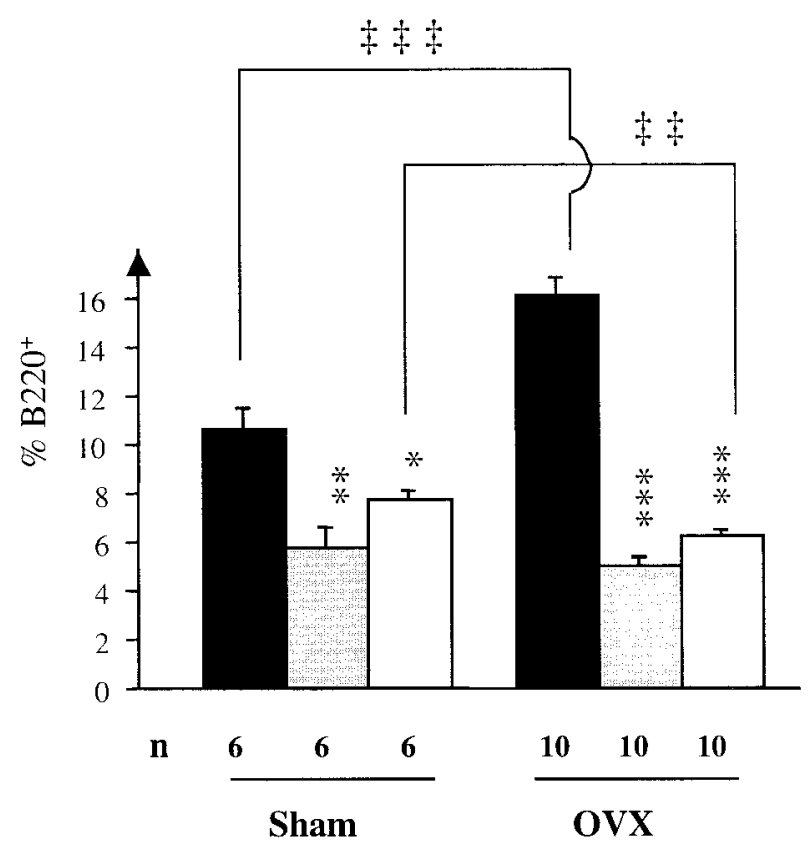

Figure 2 The percentage of $\mathrm{B} 220^{+}$cells in bone marrow of OVX or sham-operated mice treated 5 days/week for 2.5 weeks with $0.1 \mathrm{mg} / \mathrm{kg}$ E2 (shaded bars), $3 \mathrm{mg} / \mathrm{kg}$ LY (open bars) or olive oil as controls (solid bars). Bars represent means and S.E.M. ${ }^{*} P<0 \cdot 05$, ${ }^{* *} P<0 \cdot 01,{ }^{* * *} P<0 \cdot 001$ (treatment versus controls); $\neq \ddagger P<0 \cdot 01$, $\neq \neq \ddagger P<0.001$ (OVX versus sham-operated). 


\section{Controls}

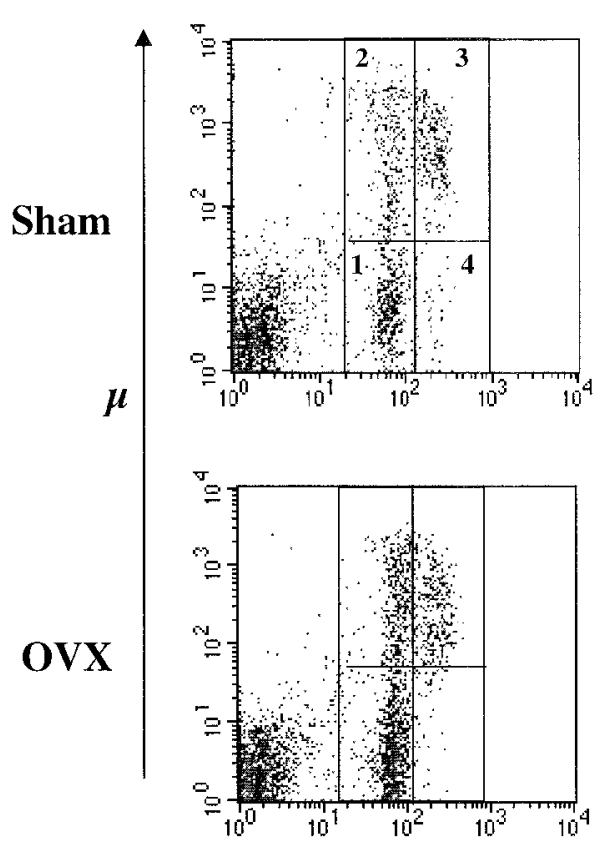

Estradiol (E2)
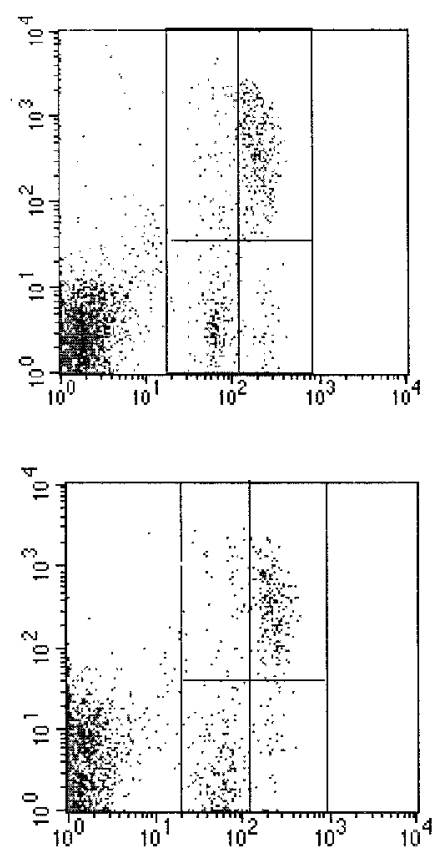

Raloxifene (LY)
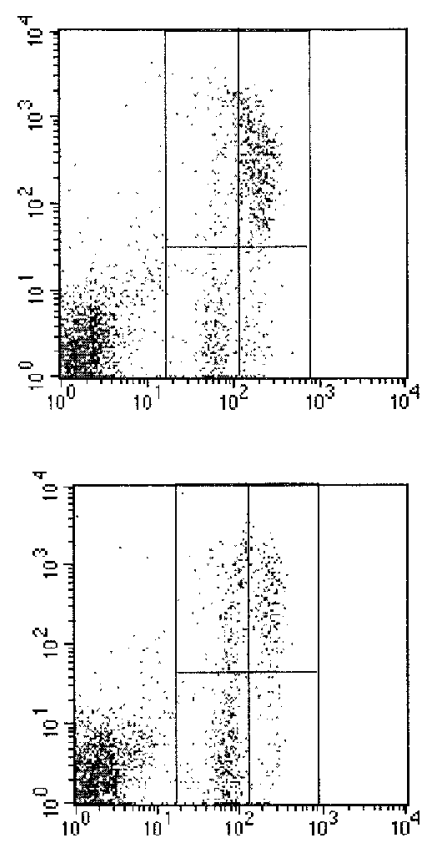

\section{B220}

Figure 3 Effects on $\mathrm{B} 220^{+}$sub-populations in bone marrow of OVX or sham-operated mice treated 5 days/week for $2 \cdot 5$ weeks with $0.1 \mathrm{mg} / \mathrm{kg} \mathrm{E2}, 3 \mathrm{mg} / \mathrm{kg} \mathrm{LY}$ or olive oil as controls. The sub-populations are numbered in order of appearance in B cell maturation: (1) B220 $0^{\text {low }} \mu^{-}$, (2) B220 $0^{\text {low }} \mu^{+}$, (3) B220 high $\mu^{+}$and (4) $B 220^{\text {high }} \mu^{-}$. Pictures are representative plots of six to ten mice in each group. Means \pm S.E.M. are shown in Table 3.

of bone-forming osteoblasts and resorbing osteoclasts. The postmenopausal osteoporosis induced by estrogen deficiency is primarily caused by an increased osteoclast formation (Pacifici 1996). Osteoclasts were formerly believed to differentiate only from stem cells of the myeloid lineage but recently osteoclasts have been shown also to differentiate from B lymphocyte precursors in the bone marrow (Manabe et al. 2001). It is suggested that this new osteoclast differentiation pathway has a role in osteoporosis caused by estrogen deficiency (Sato et al. 2001). It has also been shown that $\mathrm{T}$ lymphocytes producing tumor-necrosis factor- $\alpha$ have a role in the up-regulation of osteoclast production following OVX (Roggia et al. 2001). Taken together, the bone metabolism and the differentiation of lymphoid cells are more closely connected than was formerly believed.

We further investigated the effects of LY on mature B cell function by the use of an ELISPOT assay evaluating Ig-producing B cells in bone marrow and spleen. Estrogen treatment is known to increase the frequency of B cells actively producing Ig (Nilsson \& Carlsten 1994) and, as expected, E2 induced higher frequencies of B lym- phocytes producing Ig in both OVX and intact animals. Treatment with LY though failed to increase the frequency of spot-forming B-cells in sham-operated mice, while in OVX animals the outcome of LY treatment was similar to E2 treatment. The same pattern was found in both bone marrow (Fig. 4) and spleen (Fig. 5). Thus, raloxifene acts as an agonist on the OVX background, but not on the naïve background.

The spleen cellularity was decreased after both E2 and LY exposure as previously shown (Erlandsson et al. 2000, 2001). We have now shown that the percentage of $B$ lymphocytes in spleen decreased after exposure to both E2 and LY in OVX animals but not in sham-operated mice. The mechanism whereby estrogen regulates spleen cellularity and lymphocyte phenotypes is not known. One hypothesis is that these effects are mediated via action on the growth hormone (GH)/IGF-I axis. It has been clearly shown that Snell Dwarf mice, with impaired production of $\mathrm{GH}$, have smaller spleens and lower frequency of B cells in the spleen (Montecino-Rodriguez et al. 1997).

IGF-I has a role in up-regulating both $\mathrm{B}$ and $\mathrm{T}$ lymphopoiesis (Foster et al. 1998). IGF-I and E2 have also 


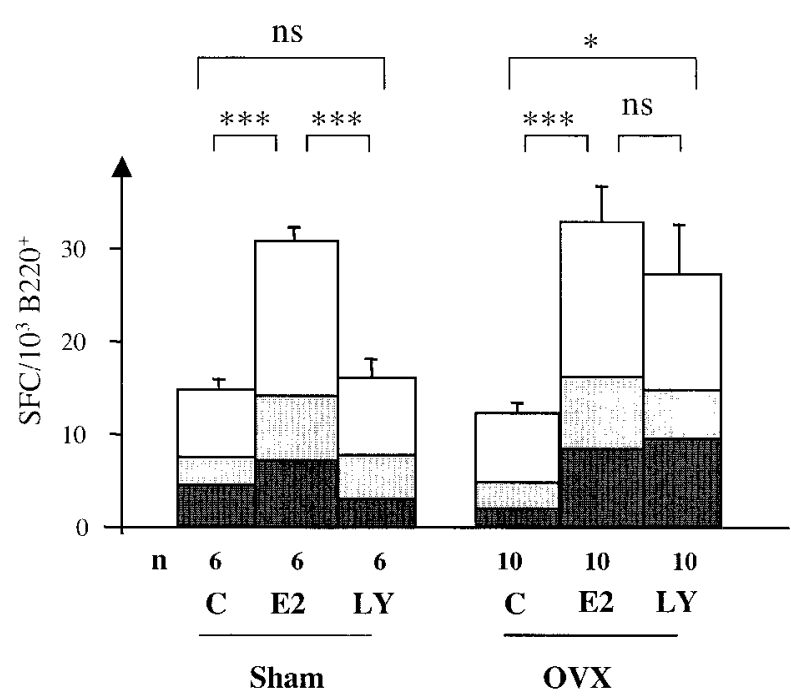

Figure 4 Effects on frequency of Ig-producing cells in the bone marrow of OVX or sham-operated mice treated 5 days/week for 2.5 weeks with $0.1 \mathrm{mg} / \mathrm{kg} \mathrm{E2,} 3 \mathrm{mg} / \mathrm{kg}$ LY or olive oil as controls (C). Data are shown as Ig SFC/1000 B220 ${ }^{+}$cells in the following order (beginning from the bottom): solid, IgM; shaded, IgG; open, $\lg$ A. Bars represent means and S.E.M. for the summation of $\lg M$, $\operatorname{lgG}$ and $\lg \mathrm{A} .{ }^{*} P<0 \cdot 05,{ }^{* *} P<0 \cdot 001$, ns, not significant.

been shown to regulate the expression of each other's receptors (Kahlert et al. 2000, Stoica et al. 2000). In addition, E2 regulates the pituitary expression of $\mathrm{GH}$, which accomplishes many of its effects through IGF-I, mainly expressed in the liver. Treatment of OVX mice with E2 tended to decrease serum levels of IGF-I (Table 5) as previously shown (Erlandsson et al. 2001). LY did not affect the serum IGF-I levels of OVX mice. In sham-

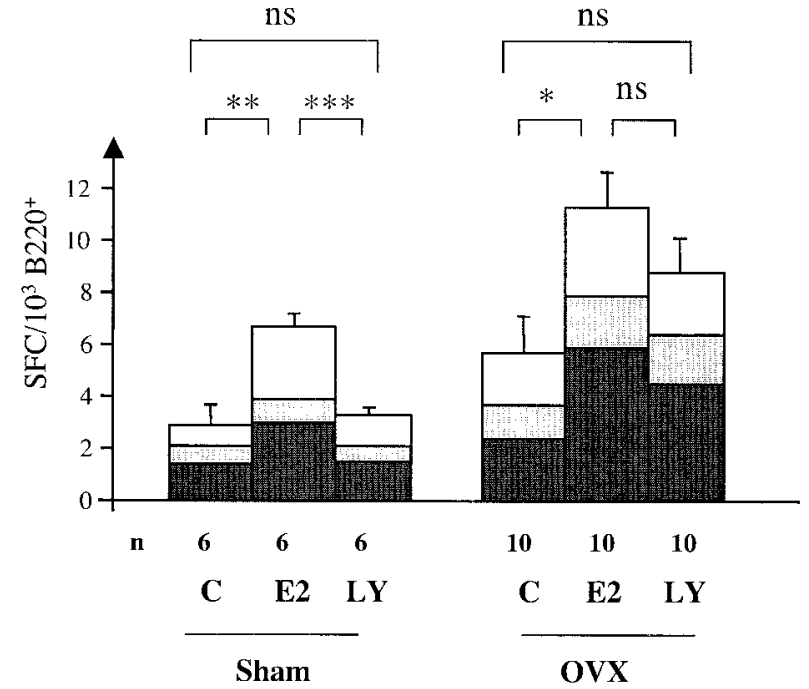

Figure 5 Effects on frequency of Ig-producing cells in the spleen of OVX or sham-operated mice treated 5 days/week for 2.5 weeks with $0.1 \mathrm{mg} / \mathrm{kg} \mathrm{E} 2,3 \mathrm{mg} / \mathrm{kg} \mathrm{LY}$ or olive oil as controls. Data are shown as Ig SFC/1000 B220 $0^{+}$cells in the following order (beginning from the bottom): solid, IgM; shaded, IgG; open, IgA. Bars represent means and S.E.M. for the summation of IgM, $\lg \mathrm{G}$ and $\lg \mathrm{A} .{ }^{*} P<0 \cdot 05,{ }^{*} P<0 \cdot 01, \mathrm{~ns}$, not significant.

operated animals, E2 had no effect while LY increased the IGF-I level, possibly indicating an antagonistic action of raloxifene on systemic IGF-I levels.

The above data suggest different effects of raloxifene exposure on different tissues or cell types. A possible mechanism for these effects is the different tissue distribution of the two known ERs, ER- $\alpha$ and ER- $\beta$. For example, ER- $\alpha$ is the dominant form expressed in the

Table 4 Number of spleen cells and frequency of cell phenotypes in spleens of mice treated with E2 or LY for 2.5 weeks. Data are presented as percentage of gated mononuclear cells. Values are means \pm S.E.M.

\begin{tabular}{|c|c|c|c|c|c|}
\hline & Treatment & $n$ & $\begin{array}{l}\text { Millions of } \\
\text { spleen cells }\end{array}$ & $\% \mathrm{~B} 220^{+}$cells & $\begin{array}{l}\text { Millions of } \\
\text { B220 }^{+} \text {splenocytes }\end{array}$ \\
\hline \multicolumn{6}{|l|}{ Operation } \\
\hline \multirow[t]{3}{*}{ Sham } & $\begin{array}{c}\text { Controls (C) } \\
\text { C vs E2 }\end{array}$ & 6 & $\begin{array}{l}169 \pm 22 \\
*\end{array}$ & $\begin{array}{l}58 \cdot 4 \pm 3 \cdot 3 \\
\mathrm{~ns}\end{array}$ & $\underset{* *}{95 \cdot 3 \pm 7 \cdot 4}$ \\
\hline & $\begin{array}{c}0 \cdot 1 \mathrm{mg} \mathrm{E} 2 / \mathrm{kg} \\
\text { E2 vs LY }\end{array}$ & 6 & $\begin{array}{l}112 \pm 6 \\
n s\end{array}$ & $\begin{array}{l}54 \cdot 7 \pm 0 \cdot 9 \\
n s\end{array}$ & $\begin{array}{l}61 \cdot 8 \pm 4 \cdot 3 \\
\text { ns }\end{array}$ \\
\hline & $\begin{array}{c}3 \mathrm{mg} \mathrm{LY} / \mathrm{kg} \\
\text { C vs LY }\end{array}$ & 6 & ${ }_{*} 98 \pm 9$ & $\begin{array}{l}55 \cdot 9 \pm 4 \cdot 0 \\
n s\end{array}$ & $\underset{* *}{55 \cdot 4 \pm 4 \cdot 3}$ \\
\hline \multirow[t]{3}{*}{ OVX } & $\begin{array}{l}\text { Controls } \\
\text { C vs E2 }\end{array}$ & 10 & $\underset{*}{224 \pm 18}$ & $\begin{array}{l}53 \cdot 5 \pm 2 \cdot 0 \\
* * *\end{array}$ & ${ }_{* * *}^{117 \cdot 6 \pm 7 \cdot 2}$ \\
\hline & $\begin{array}{c}0 \cdot 1 \mathrm{mg} \mathrm{E} 2 / \mathrm{kg} \\
\text { E2 vs LY }\end{array}$ & 10 & $\begin{array}{l}153 \pm 24 \\
\mathrm{~ns}\end{array}$ & $\begin{array}{l}37 \cdot 5 \pm 2 \cdot 0^{\ddagger \neq \neq} \\
\mathrm{ns}\end{array}$ & $\begin{array}{l}55 \cdot 5 \pm 6 \cdot 6 \\
\mathrm{~ns}\end{array}$ \\
\hline & $\begin{array}{c}3 \mathrm{mg} \mathrm{LY} / \mathrm{kg} \\
\text { C vs LY }\end{array}$ & 10 & $\begin{array}{l}130 \pm 10^{\ddagger} \\
* * *\end{array}$ & $\begin{array}{l}36 \cdot 8 \pm 1 \cdot 5^{\neq \neq \neq} \\
\star \star \star\end{array}$ & $\underset{* * *}{47 \cdot 6 \pm 3 \cdot 5}$ \\
\hline
\end{tabular}

\footnotetext{
${ }^{*} P<0 \cdot 05,{ }^{* *} P<0 \cdot 01, * * * P<0 \cdot 001$.

${ }^{\ddagger} P<0 \cdot 05,{ }^{\ddagger \ddagger \ddagger} P<0 \cdot 001$ (OVX vs sham).

ns, not significant.
} 
Table 5 Serum levels of IGF-I in mice treated with E2 or LY for 2.5 weeks. Values are means \pm S.E.M

\begin{tabular}{|c|c|c|c|c|}
\hline & $\begin{array}{l}\text { Sham } \\
(\mathrm{ng} / \mathrm{ml})\end{array}$ & $n$ & $\begin{array}{l}\boldsymbol{P} \\
\text { (sham vs } \\
\text { OVX) }\end{array}$ & $\begin{array}{l}\text { OVX } \\
(\mathrm{ng} / \mathrm{ml})\end{array}$ \\
\hline \multicolumn{5}{|l|}{ Treatment } \\
\hline $\begin{array}{c}\text { Controls (C) } \\
\text { C vs E2 }\end{array}$ & $\begin{array}{l}291 \pm 16 \\
\mathrm{~ns}\end{array}$ & 6 & ns & $\begin{array}{l}305 \pm 16 \\
\mathrm{~ns}\end{array}$ \\
\hline $\begin{array}{c}0 \cdot 1 \mathrm{mg} \mathrm{E} 2 / \mathrm{kg} \\
\text { E2 vs LY }\end{array}$ & $\begin{array}{l}297 \pm 16 \\
n s\end{array}$ & 6 & ns & $\begin{array}{l}271 \pm 15 \\
\mathrm{~ns}\end{array}$ \\
\hline $\begin{array}{c}3 \mathrm{mg} \mathrm{LY} / \mathrm{kg} \\
\mathrm{C} \text { vs LY }\end{array}$ & $\begin{array}{l}350 \pm 20 \\
*\end{array}$ & 6 & * & $\begin{array}{l}298 \pm 12 \\
\text { ns }\end{array}$ \\
\hline
\end{tabular}

${ }^{*} P<0 \cdot 05$.

ns, not significant.

uterus while, in the ovaries, both ER- $\alpha$ and ER- $\beta$ are highly expressed but with differential cellular distribution (Kuiper et al. 1998). Both ERs have also been found to varying extent in bone marrow, spleen and thymus (Couse et al. 1997, Onoe et al. 1997, Vidal et al. 1999).

A three-dimensional (3D) crystal structure of ER- $\alpha$ with raloxifene bound displays how the conformation is changed compared with the 3D structure with E2 (Brzozowski et al. 1997). When raloxifene is bound to ER- $\beta$ a similar effect is found (Pike et al. 1999). The change in conformation results in limited ability to bind tissue-specific co-activators needed for full agonistic effect (Brzozowski et al. 1997, Lonard \& Smith 2002).

Certain autoimmune diseases are affected by endogenous or added estrogen. For instance, estrogen ameliorates $\mathrm{T}$ cell and macrophage-mediated RA, but aggravates B cell and immune complex-driven SLE. Patients with both SLE and RA are at risk of developing osteoporosis as a result of chronic inflammation and long-term treatment with corticosteroids. The optimal SERM for patients with SLE should have estrogenic effects on bone formation and inflammation but not on B cells. Future development of ER- $\alpha$ - and ER- $\beta$-specific ligands could possibly help to create drugs with properties optimized for use in these patients.

\section{Acknowledgements}

We thank Mrs Lena Svensson for excellent technical assistance. We would also like to thank the SWEGENE Center for Bio-Imaging (CBI), and Göteborg University for technical support with image analysis. This study was supported by grants from the Swedish Cancer Foundation, the Börje Dahlin Foundation, the Göteborg Medical Society, the Association against Rheumatism, King Gustav V's 80 years Foundation, the Anna-Greta Crafoord Foundation, Reumaforskningsfond Margareta, the Medical Faculty of the University of Göteborg, the Swedish Foundation for Strategic Research, the Torsten and Ragnar Söderbergs Foundation, Petrus and Augusta Hedlunds Foundation and the Swedish Medical Research Council.

\section{References}

Baker VL, Draper M, Paul S, Allerheiligen S, Glant M, Shifren J \& Jaffe RB 1998 Reproductive endocrine and endometrial effects of raloxifene hydrochloride, a selective estrogen receptor modulator, in women with regular menstrual cycles. Journal of Clinical Endocrinology and Metabolism 83 6-13.

Black LJ, Sato M, Rowley ER, Magee DE, Bekele A, Williams DC, Cullinan GJ, Bendele R, Kauffman RF, Bensch WR et al. 1994 Raloxifene (LY139481 HCI) prevents bone loss and reduces serum cholesterol without causing uterine hypertrophy in ovariectomized rats. Journal of Clinical Investigation 93 63-69.

Blum WF \& Breier BH 1994 Radioimmunoassays for IGFs and IGFBPs. Growth Regulation 4 (Suppl) 11-19.

Brzozowski AM, Pike AC, Dauter Z, Hubbard RE, Bonn T, Engstrom O, Ohman L, Greene GL, Gustafsson JA \& Carlquist M 1997 Molecular basis of agonism and antagonism in the oestrogen receptor. Nature $389753-758$.

Carlsten H, Tarkowski A, Holmdahl R \& Nilsson LA 1990 Oestrogen is a potent disease accelerator in SLE-prone MRL lpr/lpr mice. Clinical and Experimental Immunology 80 467-473.

Carlsten H, Verdrengh M \& Taube M 1996 Additive effects of suboptimal doses of estrogen and cortisone on the suppression of $\mathrm{T}$ lymphocyte dependent inflammatory responses in mice. Inflammation Research 45 26-30.

Couse JF, Lindzey J, Grandien K, Gustafsson JA \& Korach KS 1997 Tissue distribution and quantitative analysis of estrogen receptoralpha (ERalpha) and estrogen receptor-beta (ERbeta) messenger ribonucleic acid in the wild-type and ERalpha-knockout mouse. Endocrinology 138 4613-4621.

Cummings SR, Eckert S, Krueger KA, Grady D, Powles TJ, Cauley JA, Norton L, Nickelsen T, Bjarnason NH, Morrow M et al. 1999 The effect of raloxifene on risk of breast cancer in postmenopausal women: results from the MORE randomized trial. Multiple outcomes of raloxifene evaluation. Journal of the American Medical Association 281 2189-2197.

Czerkinsky CC, Nilsson LA, Tarkowski A, Ouchterlony O, Jeansson S \& Gretzer C 1984 An immunoenzyme procedure for enumerating fibronectin-secreting cells. Journal of Immunoassay $\mathbf{5}$ 291-302.

Dahlgren UI \& Hanson LA 1991 Effect of oestradiol on the secretory immune system in the rat: an increase in biliary IgM antibodies against a T-cell independent antigen. Immunology 74 74-77.

Delmas PD, Bjarnason NH, Mitlak BH, Ravoux AC, Shah AS, Huster WJ, Draper M \& Christiansen C 1997 Effects of raloxifene on bone mineral density, serum cholesterol concentrations, and uterine endometrium in postmenopausal women. New England Journal of Medicine 337 1641-1647.

Erlandsson MC, Gomori E, Taube M \& Carlsten H 2000 Effects of raloxifene, a selective estrogen receptor modulator, on thymus, $\mathrm{T}$ cell reactivity, and inflammation in mice. Cellular Immunology 205 103-109.

Erlandsson MC, Ohlsson C, Gustafsson JA \& Carlsten H 2001 Role of oestrogen receptors alpha and beta in immune organ development and in oestrogen-mediated effects on thymus. Immunology 103 $17-25$.

Foster M, Montecino-Rodriguez E, Clark R \& Dorshkind K 1998 Regulation of $\mathrm{B}$ and $\mathrm{T}$ cell development by anterior pituitary hormones. Cellular and Molecular Life Sciences 54 1076-1082.

Hanna N \& Schneider M 1983 Enhancement of tumor metastasis and suppression of natural killer cell activity by beta-estradiol treatment. Journal of Immunology 130 974-980. 
Holmdahl R, Carlsten H, Jansson L \& Larsson P 1989 Oestrogen is a potent immunomodulator of murine experimental rheumatoid disease. British Journal of Rheumatology 28 (Suppl) 54-58; discussion 69-71.

Josefsson E, Tarkowski A \& Carlsten H 1992 Anti-inflammatory properties of estrogen. I. In vivo suppression of leukocyte production in bone marrow and redistribution of peripheral blood neutrophils. Cellular Immunology 142 67-78.

Kahlert S, Nuedling S, van Eickels M, Vetter H, Meyer R \& Grohe C 2000 Estrogen receptor alpha rapidly activates the IGF-1 receptor pathway. Journal of Biological Chemistry 275 18447-18453.

Kleinman D, Karas M, Danilenko M, Arbell A, Roberts CT, LeRoith D, Levy J \& Sharoni Y 1996 Stimulation of endometrial cancer cell growth by tamoxifen is associated with increased insulin-like growth factor (IGF)-I induced tyrosine phosphorylation and reduction in IGF binding proteins. Endocrinology 137 1089-1095.

Kuiper GG, Shughrue PJ, Merchenthaler I \& Gustafsson JA 1998 The estrogen receptor beta subtype: a novel mediator of estrogen action in neuroendocrine systems. Frontiers in Neuroendocrinology 19 253-286.

Lonard DM \& Smith CL 2002 Molecular perspectives on selective estrogen receptor modulators (SERMs): progress in understanding their tissue-specific agonist and antagonist actions. Steroids 67 $15-24$.

Manabe N, Kawaguchi H, Chikuda H, Miyaura C, Inada M, Nagai R, Nabeshima Y, Nakamura K, Sinclair AM, Scheuermann RH et al. 2001 Connection between B lymphocyte and osteoclast differentiation pathways. Journal of Immunology 167 2625-2631.

Masuzawa T, Miyaura C, Onoe Y, Kusano K, Ohta H, Nozawa S \& Suda T 1994 Estrogen deficiency stimulates B lymphopoiesis in mouse bone marrow. Journal of Clinical Investigation 94 1090-1097.

Medina KL, Smithson G \& Kincade PW 1993 Suppression of B lymphopoiesis during normal pregnancy. Journal of Experimental Medicine 178 1507-1515.

Medina KL, Strasser A \& Kincade PW 2000 Estrogen influences the differentiation, proliferation, and survival of early B-lineage precursors. Blood 95 2059-2067.

Montecino-Rodriguez E, Clark RG, Powell-Braxton L \& Dorshkind K 1997 Primary B cell development is impaired in mice with defects of the pituitary/thyroid axis. Journal of Immunology 159 2712-2719.

Nilsson N \& Carlsten H 1994 Estrogen induces suppression of natural killer cell cytotoxicity and augmentation of polyclonal B cell activation. Cellular Immunology 158 131-139.

Onoe Y, Miyaura C, Ohta H, Nozawa S \& Suda T 1997 Expression of estrogen receptor beta in rat bone. Endocrinology 138 4509-4512.

Onoe Y, Miyaura C, Ito M, Ohta H, Nozawa S \& Suda T 2000 Comparative effects of estrogen and raloxifene on B lymphopoiesis and bone loss induced by sex steroid deficiency in mice. Journal of Bone and Mineral Research 15 541-549.

Ostensen M 1999 Sex hormones and pregnancy in rheumatoid arthritis and systemic lupus erythematosus. Annals of the New York Academy of Sciences 876 131-143; discussion 44.

Pacifici R 1996 Estrogen, cytokines, and pathogenesis of postmenopausal osteoporosis. Journal of Bone and Mineral Research 8 $1043-1051$.

Pike AC, Brzozowski AM, Hubbard RE, Bonn T, Thorsell AG, Engstrom O, Ljunggren J, Gustafsson JA \& Carlquist M 1999 Structure of the ligand-binding domain of oestrogen receptor beta in the presence of a partial agonist and a full antagonist. EMBO Journal 18 4608-4618.

Rijhsinghani AG, Thompson K, Bhatia SK \& Waldschmidt TJ 1996 Estrogen blocks early T cell development in the thymus. American Journal of Reproductive Immunology 36 269-277.

Roggia C, Gao Y, Cenci S, Weitzmann MN, Toraldo G, Isaia G \& Pacifici R 2001 Up-regulation of TNF-producing T cells in the bone marrow: a key mechanism by which estrogen deficiency induces bone loss in vivo. PNAS 98 13960-13965.

Samuels A, Perry MJ \& Tobias JH 1999 High-dose estrogen induces de novo medullary bone formation in female mice. Journal of Bone and Mineral Research 14 178-186.

Sato M, Kim J, Short LL, Slemenda CW \& Bryant HU 1995 Longitudinal and cross-sectional analysis of raloxifene effects on tibiae from ovariectomized aged rats. Journal of Pharmacology and Experimental Therapeutics 272 1252-1259.

Sato M, Rippy MK \& Bryant HU 1996 Raloxifene, tamoxifen, nafoxidine, or estrogen effects on reproductive and nonreproductive tissues in ovariectomized rats. FASEB Journal 10 905-912.

Sato T, Shibata T, Ikeda K \& Watanabe K 2001 Generation of bone-resorbing osteoclasts from B220+ cells: its role in accelerated osteoclastogenesis due to estrogen deficiency. Journal of Bone and Mineral Research 16 2215-2221.

Stoica A, Saceda M, Fakhro A, Joyner M \& Martin MB 2000 Role of insulin-like growth factor-I in regulating estrogen receptor-alpha gene expression. Journal of Cellular Biochemistry 76 605-614.

Vidal O, Kindblom LG \& Ohlsson C 1999 Expression and localization of estrogen receptor-beta in murine and human bone. Journal of Bone and Mineral Research 14 923-929.

Vidal O, Lindberg M, Hollberg K, Baylink DJ, Andersson G, Lubahn DB, Mohan S, Gustafsson JA \& Ohlsson C 2000 Estrogen receptor specificity in the regulation of skeletal changes in male mice. PNAS 97 5474-5479.

Received 26 April 2002

Accepted 15 July 2002 